\title{
Sea urchins, El Niños, and the long term stability of Southern California kelp forest communities
}

\author{
M. J. Tegner, P. K. Dayton \\ Scripps Institution of Oceanography, University of California, San Diego, La Jolla, California, 92093-0201, USA
}

\begin{abstract}
Southern California kelp forests experienced major losses during the El Niño of 1957-1959. The proximal reason for the decline was ascribed to sea urchin grazing, and the eventual recovery of some forests followed sea urchin control efforts, kelp restoration, and improvements in sewage disposal practices. The very strong El Niño of 1982-84 allowed us to reexamine hypotheses regarding the interactions between kelps, sea urchins, and warm water, and to speculate about what happened during the earlier El Niño. Algal drift abundance, urchin recruitment rates, and changes in urchin density were followed at 5 sites in the Point Loma kelp forest near San Diego from 1983 to 1987. Sea urchin recruitment rates were very low during 1982-84 and the apparent reasons for this, namely decreased reproduction, depauperate planktonic conditions, and altered current patterns, probably prevailed during the earlier El Niño as well. Algal drift did not become limiting during the recent event, but urchin grazing was triggered at one site in 1987 after an amphipod infestation had reduced kelp biomass, and urchin recruitment and migration had increased grazing pressure. The Point Loma kelp forest showed significant recovery the year after the 1982-84 El Niño, something that took over 5 yr in the 1960s. Decline in the density of red urchins Strongylocentrotus franciscanus since the mid 1970 s suggests that the fishery for this species, which became extensive in the late 1970s, was an important contributor to the faster kelp recovery. In the absence of evidence for increased recruitment or temperature effects on grazing demand, it appears that the destructive grazing observed during and after the El Niño of 1957-59 resulted from reductions in kelp standing stock and productivity below levels necessary to satisfy the existing grazing demand.
\end{abstract}

\section{INTRODUCTION}

Surveyed at large sizes in 1857 and 1911, certain of the coastal kelp forests of Southern California began to decline in surface area about 1940 and all experienced major losses during the El Niño of 1957-59. Many forests remained at low levels midway into the 1960 s (North 1971, 1974, 1983, Harger 1983, Dayton et al. 1984). Systematic diving investigation of these communities began in 1956 and the proximal reason for the decline of the forests was determined to be intense sea urchin grazing (North 1964, Leighton et al. 1966, North $\&$ Pearse 1970). An 'apparent population explosion' of red (Strongylocentrotus fransciscanus) and purple (S. purpuratus) urchins was reported to have replaced many once luxuriant forests of giant kelp Macrocystis pyrifera, and their continued grazing pressure prevented reestablishment of the vegetation (North \& Pearse 1970). The eventual recovery of forests near the metropolitan areas of Los Angeles and San Diego followed urchin control programs, kelp restoration, and improved sewage disposal practices (Wilson et al. 1977, Mearns \& Young 1983, North 1983).

Several hypotheses concerning the interactions between kelps, sea urchins, and El Niño events have been proposed to explain the extreme disruption of kelp forest communities observed 3 decades ago (Leighton et al. 1966, Tegner \& Dayton 1987). These fall into 2 general categories. First, environmental conditions such as storms, warm water, or low light levels could reduce kelp standing stocks and/or productivity below the level needed to satisfy existing grazing demand. Second, grazing demand could increase due to increased sea urchin recruitment, movement, or decreased predation rates. Leighton et al. (1966) further suggest that sea urchin grazing rates rise faster than kelp growth rates in warm water. Some combination of these hypotheses is a likely explanation.

The 1982-84 El Niño provided an opportunity to reexamine how warm water events affect the relationship between kelps and sea urchins in Southern California. The Point Loma kelp forest near San Diego 
is one of the best known kelp communities in the world, having been under nearly continuous study since 1956 (e. g. North 1964, 1971, Tegner \& Dayton 1981, 1987. Dayton \& Tegner 1984, 1990, Dayton et al. 1984). After about 15 yr of relative stability, the population of Macrocystis pyrifera in this kelp forest was again devastated by the storms and warm water of the more recent El Nin̄o (Dayton \& Tegner 1984, 1990, Tegner \& Dayton 1987). Here we report how this event affected the availability of algal drift the primary food of these grazers), the patterns of sea urchin recruitment at 5 sites before, during, and after this event, and changes in urchin density and behavior within the Point Loma forest. Despite the larger physical disturbance of the recent El Niño, many coastal kelp forests recovered much faster than after the 1957-1959 event (Tegner \& Dayton 1987). Comparisons of urchin density between the mid 1970s (Tegner \& Dayton 1981) and the 1980 s indicate that the commercial fishery for red sea urchins has greatly reduced their population. We speculate that the fishery has increased the long-term stability of this system by allowing faster kelp recovery after disturbance.

\section{STUDY AREAS AND METHODS}

The Point Loma kelp forest is located offshore of San Diego, California $\left(32^{\circ} 42^{\prime} \mathrm{N} ; 117^{\circ} 16^{\prime} \mathrm{W}\right)$. This large forest, generally about 8 to $10 \mathrm{~km}$ long by $1 \mathrm{~km}$ wide, is located on a broad, gently sloping, mudstonesandstone terrace with pockets of reefs, boulders, and sand. Sea urchin populations were studied at 3 sites in the central region of the forest, chosen to represent the outer (18 $\mathrm{m} \mathrm{C}$ ) and inner (12 $\mathrm{m} \mathrm{C}$ ) edges and the middepths $(15 \mathrm{~m} \mathrm{C})$ of the forest, during the period 1974 to 1977 (Tegner \& Dayton 1981). Two additional sites, North (18 $\mathrm{m} \mathrm{N})$ and South $(18 \mathrm{~m} \mathrm{~S})$, were added in 1983 to consider the effects of longshore currents on the outer edge of the forest. These sites are mapped in Tegner \& Dayton (1987). Four parallel $25 \mathrm{~m}$ lead core line transects were permanently installed in an offshore-onshore direction at each site in 1983. These transects were placed in areas of maximal habitat uniformity at each site and their spacing forms a square $25 \mathrm{~m}$ on a side.

To determine changes in the availability of sea urchin food, algal drift (plus fragments of seagrass Phyllospadix spp.) was collected at approximately monthly intervals from each site from spring 1983 through the end of 1986 . Divers removed all algal fragments (including those held by urchins) visible without moving animals or rocks, from $2 \mathrm{~m}$ to both sides of each transect. If the quantities of drift were impractically large, the lines were subsampled. No collections were made in the summer and fall of 1983 at $12 \mathrm{~m} \mathrm{C}$ because a dense bloom of Desmarestia ligulata made it impossible to follow the transect lines. The drift was brought back to the laboratory, sorted to species, and weighed. Marcrocystis was further sorted into blades, stipes, fronds (blades still on stipes), sporophylls, and haptera.

Sea urchin recruitment was assessed from sizefrequency distributions which were sampled twice a year during winter-spring and fall, with the exception of fall 1984. A $1 \mathrm{~m}^{2}$ frame was haphazardly placed over aggregations of urchins in boulder piles away from the transects at each site and the boulder piles were completely torn apart to search for urchins. We attempted to measure a minimum of 100 individuals of each species per sample. As purple urchins greatly outnumbered red urchins at $12 \mathrm{~m} \mathrm{C}$, additional $1 \mathrm{~m}^{2}$ samples of only the latter species were searched to obtain an adequate sample size. Test diameter was measured to the nearest millimeter with vernier calipers. Urchins smaller than about $10 \mathrm{~mm}$ are not quantitatively sampled by this method (Tegner \& Dayton 1981).

Recruitment rates are presented as percent young of the year in the population at each site. Sea urchin density is highly variable among sites at Point Loma, largely due to differences in habitat structure where the size-frequency samples were taken, although density remained fairly constant within most sites during the 1980s (see 'Results'). Thus it would be misleading to compare recruitment rates in terms of density in the size-frequency distribution samples among sites, but examples of recruitment rates in terms of density will be presented comparing changes between decades for 2 sites. Again because of the high variability in habitat where the urchin aggregations are sampled, the results from the $\mathrm{m}^{2}$ samples are pooled and one value of percent recruitment is calculated per sampling period per site.

Sea urchin density was determined annually in the spring on the permanent transects at each site. All urchins which could be seen with the use of a light but without turning rocks or moving animals were counted in 10 quadrats $(5 \times 2 \mathrm{~m})$ along the lines. After testing for homogeneity of variances $(p<0.05)$, ANOVA tests were run on log-transformed data.

In situ bottom temperatures were collected with recording Ryan thermographs. The thermographs were deployed for 3 mo at a time and were calibrated at the beginning and the end of each deployment. Temperatures were determined every $3 \mathrm{~h}$ from the continuous record ( 8 values $\mathrm{d}^{-1}$ ), adjusted for the calibration and averaged by month. Gaps in the record were minimized by the availability of an extra thermograph with which to replace an instrument at the end of its deployment. 


\section{RESULTS}

\section{Availability of algal drift}

Changes in the abundance of algal drift from 1983 to 1987 at the 3 outer and 3 central sites are plotted in Fig. 1. Several patterns are apparent. As reported by Gerard (1976), Harrold \& Reed (1985), and Druehl \& Breen (1986), there was a strong seasonal signal in drift abundance. Drift abundance was minimal during the winter and increased each quarter to its maximal abundance in fall (Fig. 2). The seasonal signal was altered in 1985 (Fig. 1) by bursts of amphipod grazing (Tegner \& Dayton 1987). Drift abundance was very low in 1983 and 1984, and then increased each year as the kelp forest recovered from the El Niño. In the central forest, there was an increase in drift abundance with decreasing depth. Drift abundance was less than $0.1 \mathrm{~g}$ $\mathrm{m}^{-2}$ at $18 \mathrm{~m} \mathrm{~S}$ in 3 collections and less than $1.0 \mathrm{~g} \mathrm{~m}^{-2}$ on a total of 6 occasions in 1985 and 1986, after the El Niño. With the exception of one collection at $12 \mathrm{~m} \mathrm{C}$ in March 1984 which averaged $0.8 \mathrm{~g} \mathrm{~m}^{-2}$, no other samples fell below $1 \mathrm{~g} \mathrm{~m}^{-2}$ during the $4 \mathrm{yr}$ of the study; some algal drift was almost always available to grazers during the height of the El Niño disturbances to the Macrocystis populaton. Values for individual collections ranged as high as $103.4 \mathrm{~g} \mathrm{~m}^{-2}$ for $12 \mathrm{~m} \mathrm{C}$ in July 1986. Because the data were not expected to be normal and the samples were too unevenly distributed in time and space to use parametric statistics, the distribution of values above and below the grand median was tested with a 3-way chi square analysis (Sokal \& Rohlf 1969). The median value of drift abundance was $12.3 \mathrm{~g}$ $\mathrm{m}^{-2}$ and there were significant differences among sites $(p<0.05)$ and especially among seasons $(p<0.001)$. Average values of a drift collection by site and by season (Fig. 2) further suggest when and where sea urchins are most likely to become food limited.

Because both red and purple urchins have distinct food preferences (Leighton 1966), we determined the species composition of the drift. The composition of all drift samples summed ( $\mathrm{n}=131$ samples) is broken down in Table 1. The drift was strongly dominated by Macrocystis pyrifera (85\%), and laminarians accounted for $97 \%$ of the total. The interannual variation in the percent of the total drift constituted by giant kelp is illustrated in Fig. 3. Despite the major disruption of Macrocystis populations by storms and warm water during the El Niño (Tegner \& Dayton 1987), its annual contribution to the drift never dropped below $65 \%$, except at $18 \mathrm{~m} \mathrm{~S}$ where the values were $60 \%$ in 1985 and $36 \%$ in 1986; in both these years the total drift abundances were very low at this site (Fig. 1). More typically, Macrocystis represented $69 \%$ of the drift at $18 \mathrm{~m} \mathrm{C}$ after the disturbances of 1983, and this

\section{A. Central Forest Sites}

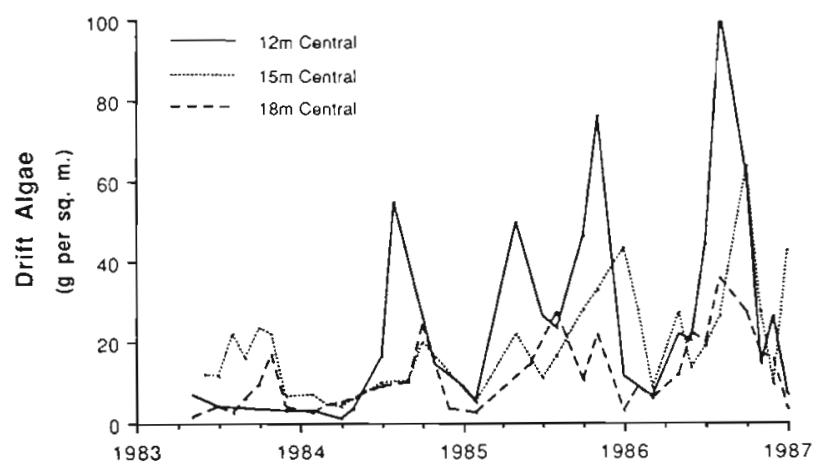

B. Outer Edge Sites

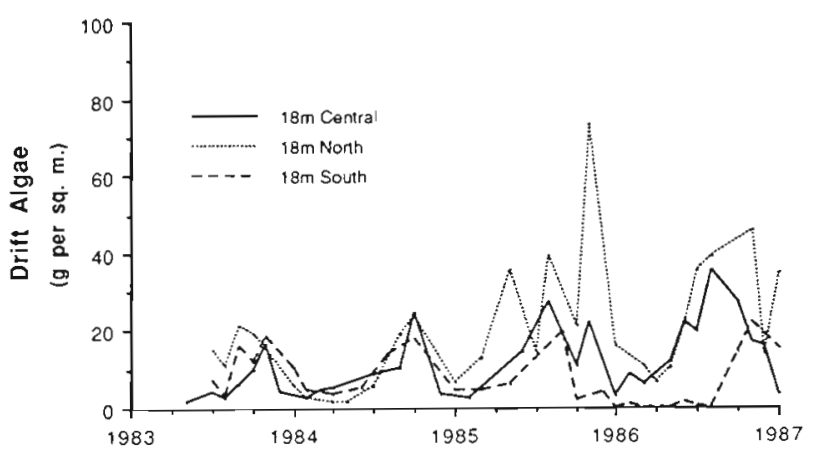

Fig. 1. Biomass of drift algae (wet weight) over time from spring 1983 through the end of 1986 . Samples were collected from $400 \mathrm{~m}^{2}$ per site at approximately monthly intervals. (A) Central forest sites. (B) Outer edge sites

increased to $93 \%$ in 1985 and $98 \%$ in 1986 (Fig. 3). At $18 \mathrm{~m} \mathrm{~N}$, which like $18 \mathrm{~m} \mathrm{~S}$ suffered less summer mortality of Macrocystis than $18 \mathrm{~m} \mathrm{C}$ during 1983 (Tegner \& Dayton 1987), the annual contribution of giant kelp to the drift never dropped below $87 \%$. While the percent Macrocystis increased at the shallower sites after the major disturbances, it remained at lower levels than the outer edge sites in 1986 and 1987 because lower standing kelps are normally more abundant at these depths than at $18 \mathrm{~m}$.

\section{Recruitment}

The patterns of red and purple urchin recruitment in the Point Loma kelp forest for 1983 to 1987 are shown in Fig. 4. We define recruitment as that portion of the population consisting of young-of-the-year individuals, based on growth rates determined locally. These are red urchins to $35 \mathrm{~mm}$ (Tegner \& Barry unpubl.) and purple urchins to $25 \mathrm{~mm}$ (Ebert 1977). The general pattern of recruitment was very low for both species 


\section{A. Average Drift By Site}

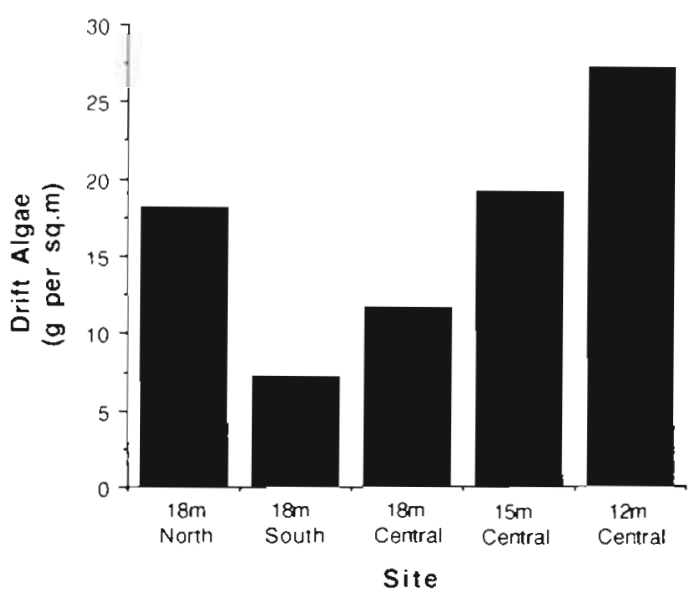

B. Average Orift By Season

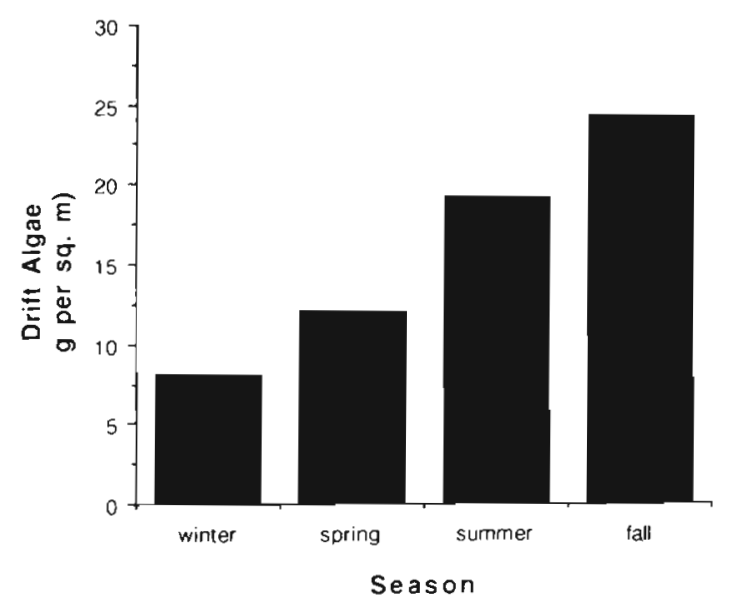

Fig. 2. (A) Average drift by site, all samples combined, spring 1983 through the end of 1986 . (B) Average drift by season, all sites combined, spring 1983 through the end of 1986 . Sites, and especially seasons, were significantly different (see text)

during 1983 to 1985, including cases of zero values for both species, followed by increases in 1986 and 1987. These curves suggest that recruitment was consistently better at edge of the forest sites than inside the bed. To test this hypothesis, recruitment rates were ranked for each of the 9 determinations at the 5 sites and analyzed with the Friedman 2-way ANOVA. The rankings were significant for both species $(\mathrm{p}<0.01)$. A posteriori tests (Nemenyi 1963) were conducted to determine which sites were significantly different. The mean percent recruitment (1983 to 1987) for each site in the order of its ranking is given in Table 2 . Thus, while there may have been minor differences between the 2 species,
Table 1. Species composition of all drift collections ( $\mathrm{n}=131$ ) from all 5 sites from 1983 through 1986. Macrocystis pyrifera is also broken down by parts of the plant

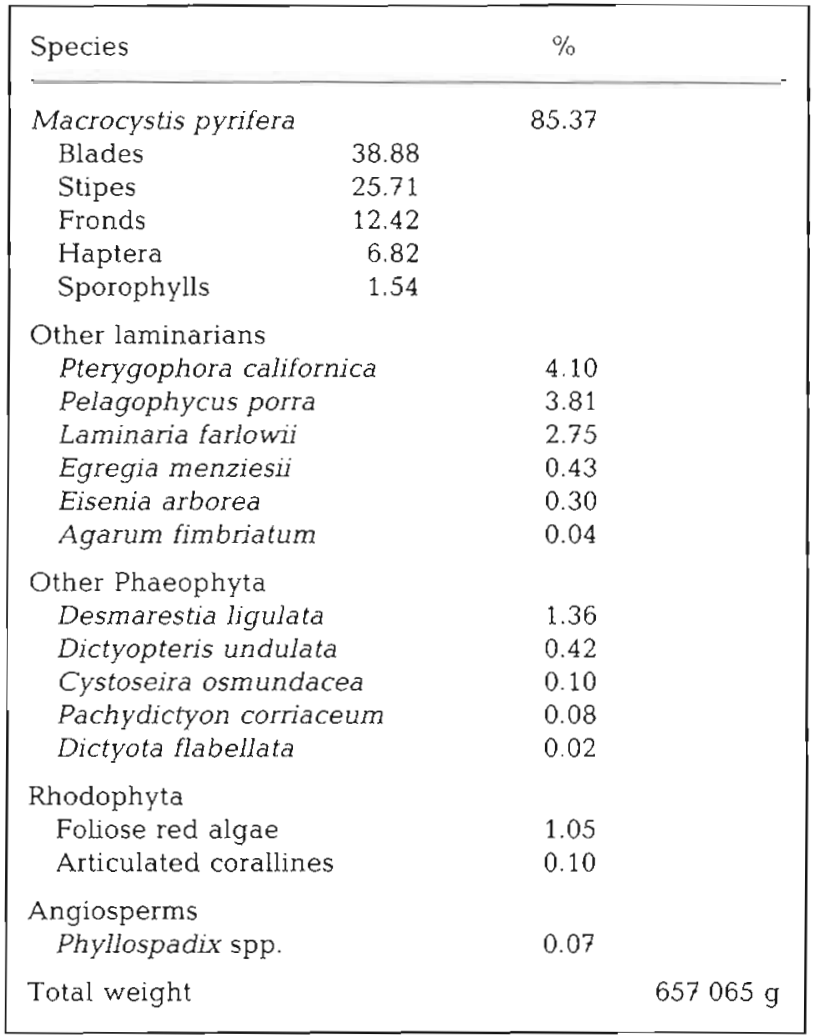

A. Central Forest Sites

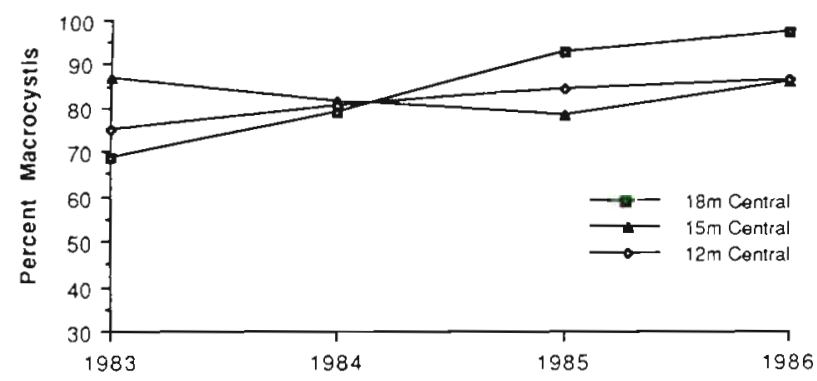

B. Outer Edge Siles

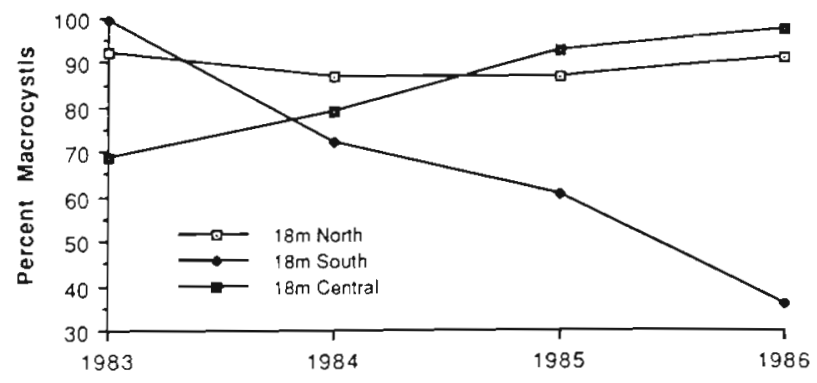

Fig. 3. Macrocystis pyrifera. Variance in the percentage of the drift constituted by $M$. pyrifera, spring 1983 through the end of 1986, by year. (A) Central forest sites. (B) Outer edge sites 
Table 2. Strongylocentrotus franciscanus and S. purpuratus. Mean percent recruitment from 1983 to 1987 at sites in rank order Lines connect values which are not significantly different

\begin{tabular}{|c|c|c|c|c|}
\hline \multicolumn{5}{|c|}{ S. franciscanus: } \\
\hline $\begin{array}{c}18 \mathrm{~m} \mathrm{C} \\
30.7\end{array}$ & $\begin{array}{c}18 \mathrm{~m} \mathrm{~S} \\
36.8\end{array}$ & $\begin{array}{c}18 \mathrm{~m} \mathrm{~N} \\
22.7\end{array}$ & $\begin{array}{c}15 \mathrm{~m} \mathrm{C} \\
7.9\end{array}$ & $\begin{array}{c}12 \mathrm{~m} \mathrm{C} \\
2.8\end{array}$ \\
\hline \multicolumn{5}{|c|}{ S. purpuratus: } \\
\hline $18 \mathrm{~m} \mathrm{~S}$ & $18 \mathrm{~m} \mathrm{C}$ & $18 \mathrm{~m} \mathrm{~N}$ & $15 \mathrm{~m} \mathrm{C}$ & $12 \mathrm{~m} \mathrm{C}$ \\
\hline 25.6 & 16.4 & 8.9 & 5.2 & 3.2 \\
\hline
\end{tabular}

A. Strongylocentrotus purpuratus

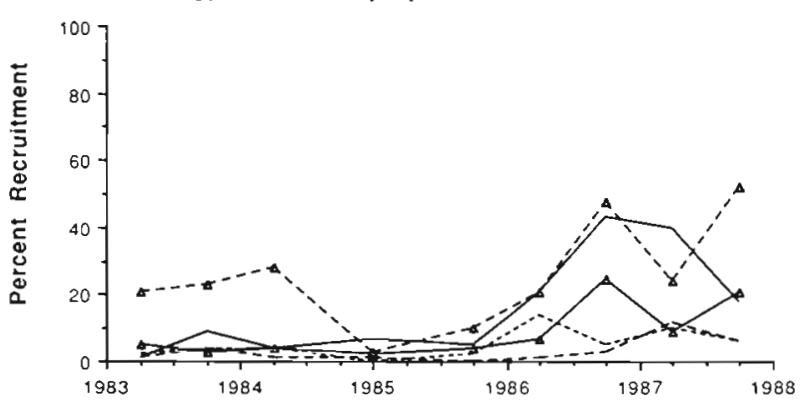

B. Strongylocentrotus tranciscanus

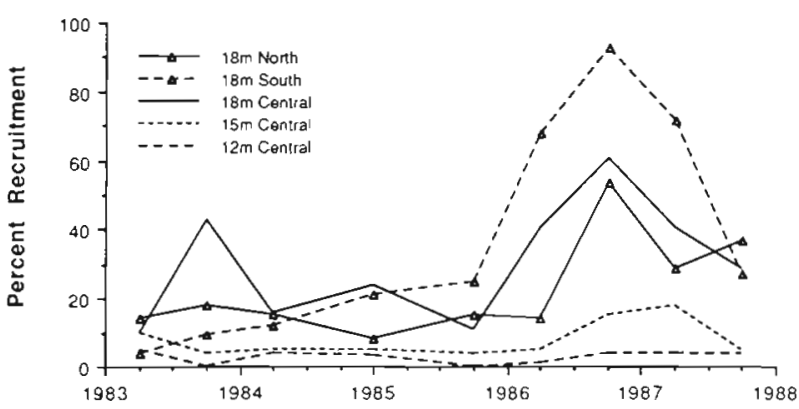

Fig. 4. Strongylocentrotus purpuratus and S. franciscanus. Sea urchin recruitment rates by site, 1983 through 1987, based on $\mathrm{m}^{2}$ collections from urchin aggregations taken twice a year. Recruitment rates are expressed as the proportion of the total population represented by young-of-the-year. (A) Purple urchins $S$. purpuratus. (B) Red urchins $S$. franciscanus

both recruited most heavily along the outer edge of the forest and there was consistently less recruitment within the bed.

While growth rates of very young sea urchins are not well known, it is possible to make a rough estimate of time of settlement from the presence of individuals less than half of the size at 1 yr. For red urchins, $36 \%$ of the urchins in this size category were collected in the spring samples and $64 \%$ in the fall ( $n=783$ ). The appearance of small purple urchins was more evenly distributed; $51 \%$ were found in the spring and $49 \%$ in the fall ( $\mathrm{n}=553$ ). With the exception of $18 \mathrm{~m} \mathrm{~S}$ during the latter part of the study, all size-frequency samples were taken from areas where algal drift was abundant; thus the presence of young individuals in both the spring and fall is likely to reflect extended settlement periods, not growth limitation.

Recruitment rates were recalculated on an annual basis and compared with rates observed in the mid 1970 s (Tegner \& Dayton 1981), when size frequency distributions were sampled monthly at the central Point Loma sites (Fig. 5). Recruitment rates of both species were very low at $18 \mathrm{~m} \mathrm{C}$ from 1983 to 1985 relative to the mid 1970 s, but then recovered to comparable rates. While the $15 \mathrm{~m} \mathrm{C}$ site showed some recovery from the low levels of recruitment during and immediately after the El Niño, both the 15 and $12 \mathrm{~m} \mathrm{C}$ sites remain at very low levels relative to the mid 1970 s.

Juvenile red sea urchins are strongly associated with conspecific adults, and are predominantly found under or adjacent to the adult spine canopy (Tegner \& Dayton 1977). This is a social behavior which offers juvenile urchins protection from predation and a share of the adult's food (Tegner \& Levin 1983, Breen et al. 1985). Furthermore, red urchin populations with a wide size range of adults often show a significant increase in the number of juvenile urchins sheltered per adult with increasing adult size (Tegner 1989). Thus it is important to consider whether the urchin fishery, which has affected both adult density and average size of the canopy providers, has affected the nursery function of adults. To compare the mid 1970 s with 1983 to 1987 , we computed the densities of young-of-the-year juveniles and adults greater than $100 \mathrm{~mm}$ in the $\mathrm{m}^{2}$ samples at 18 and $12 \mathrm{~m} \mathrm{C}$. The density of juveniles in the boulder pile samples at $18 \mathrm{~m} \mathrm{C}$ decreased during and immediately after the El Niño, but by 1986 had increased to values comparable to the mid 1970s (Fig. 6); there was no significant difference in the density of young-of-theyear juveniles comparing annual means for the mid 1970 s and the mid 1980 s ( $t$-test, $p=0.24$ ). The density of large adults and the total density, however, declined significantly between mid 1970s and the mid 1980s ( $t$-tests, $p=0.0017$ and 0.037 , respectively), and remained low during the study. In contrast, at $12 \mathrm{~m} \mathrm{C}$ large adults were rare throughout the 1980 s and recruitment rates did not recover after the El Niño (Fig. 6). Here there were significant decreases in young-of-theyear juvenile, large adult, and total densities ( $t$-tests, $\mathrm{p}=$ $0.021,0.004$, and 0.008 , respectively).

\section{Changes in density}

Densities of red and purple urchins on the permanent transect lines did not change significantly from 1983 

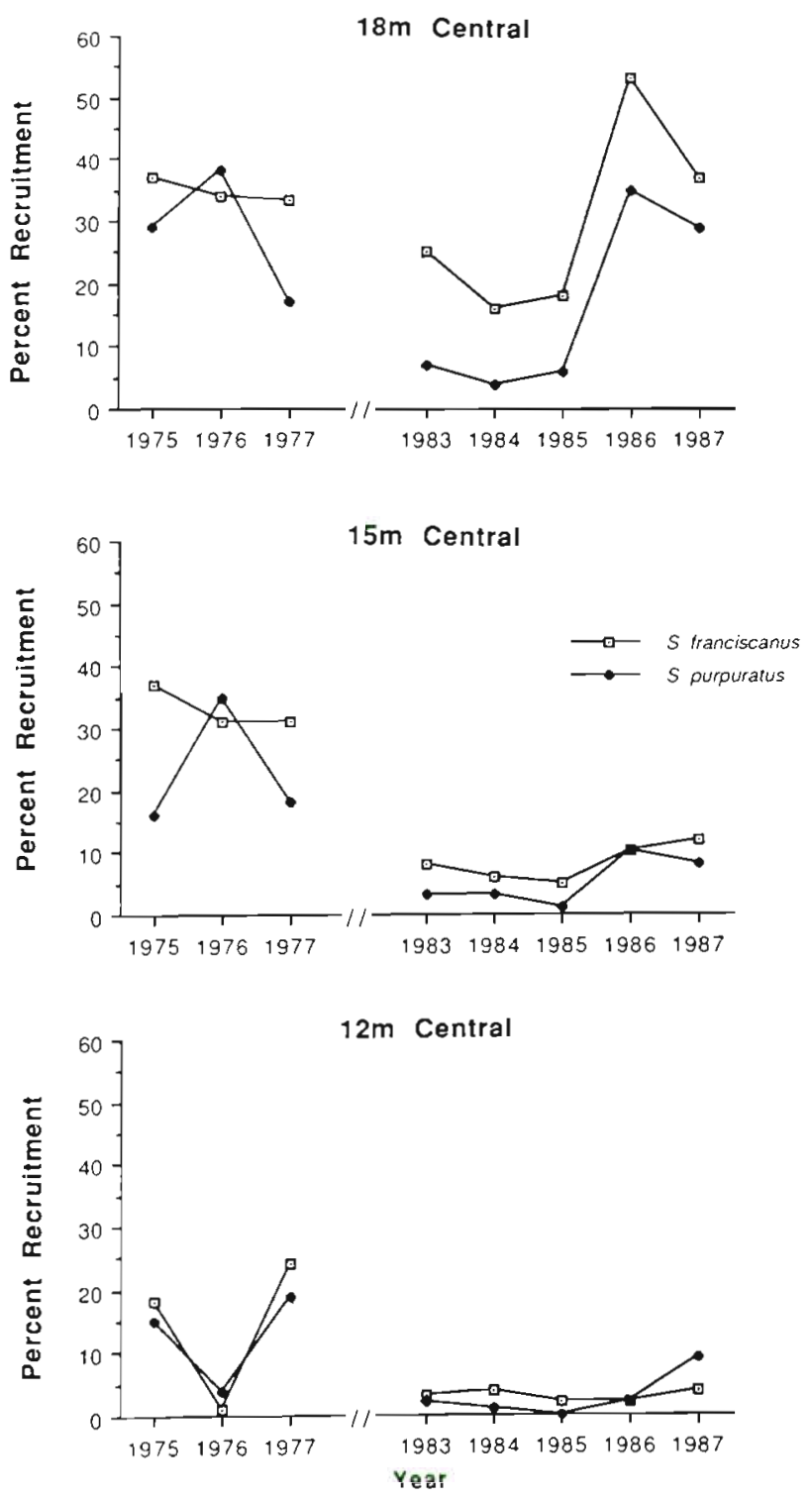

Fig. 5. Strongylocentrotus purpuratus and $S$ franciscanus. Recruitment rates during the mid 1970 s (Tegner \& Dayton 1981) compared with 1983 to 1987 as computed on an annual basis for 3 sites in the central forest. Data were computed from $\mathrm{m}^{2}$ samples of urchin aggregations

through 1987 at 4 of the 5 study sites (Fig. 7 ; ANOVA, p $>0.05)$. The densities of both species increased at $18 \mathrm{~m}$ $\mathrm{S}(\mathrm{p}<0.001$ in each case $)$. At this site, an examination of the density changes line by line illustrates that some of the increase can be attributed to migration from an urchin-dominated area south of line $\mathrm{D}$, which increased faster than line C, etc. (Fig. 8). However, increases in recruitment also preceded increases in density, especially for Strongylocentrotus franciscanus (Fig. 9).

Densities from the mid 1980s are compared with values obtained in 1975 (Tegner \& Dayton 1981) in
Fig. 10. Densities were determined once in 1975 on $100 \times 2 \mathrm{~m}$ transects at the 12 and $18 \mathrm{~m} \mathrm{C}$ sites running through the same areas as the present $25 \mathrm{~m}$ transects; the habitats are similar but not identical. (The densities at $12 \mathrm{~m}$ C were reported incorrectly in Tegner \& Dayton 1981. The values should be 0.8 and $2.1 \mathrm{~m}^{-2}$ for Strongylocentrotus franciscanus and $S$. purpuratus, respectively.) Purple urchin densities do not appear to have changed since 1975, but red urchin densities have been reduced by 1 to 2 orders of magnitude. The purple to red urchin ratio has increased from 1.6 to 14.6 at $18 \mathrm{~m} \mathrm{C}$ and from 2.8 to 291 at $12 \mathrm{~m} \mathrm{C}$.

\section{Description of events at $18 \mathrm{~m} \mathrm{~S}$}

Until the fall of 1984, there was no indication that $18 \mathrm{~m} \mathrm{~S}$ was different from other forest edge sites. At that time plants were stressed throughout the forest

\section{A. $18 \mathrm{~m}$ Central}



B. $12 \mathrm{~m}$ Central

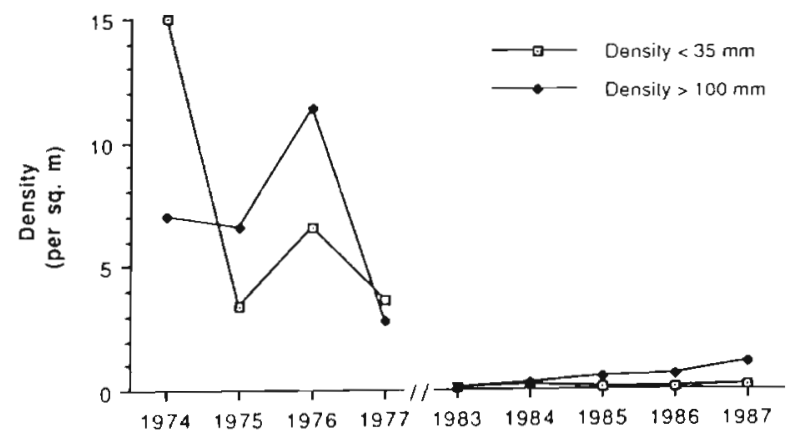

Fig. 6. Strongylocentrotus franciscanus. Densities of young-ofthe-year and large adult red urchins from the mid 1970 s (Tegner \& Dayton 1981) and 1983 to 1987 at $18 \mathrm{~m} \mathrm{C}$ and $12 \mathrm{~m}$ $C$ sites computed from the $\mathrm{m}^{2}$ samples of urchin aggregations. The decline in adult density between the mid 1970 s and the 1980 s was significant at both sites and juvenile recruitment was significantly lower at $12 \mathrm{~m} \mathrm{C}$ in the 1980 s (see text) 


\section{A. Strongylocentrotus purpuratus}

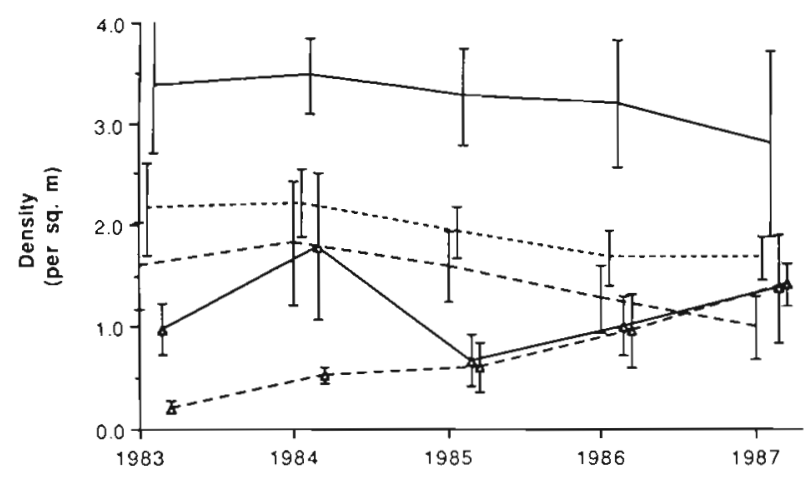

B. Strongylocentrotus franciscanus

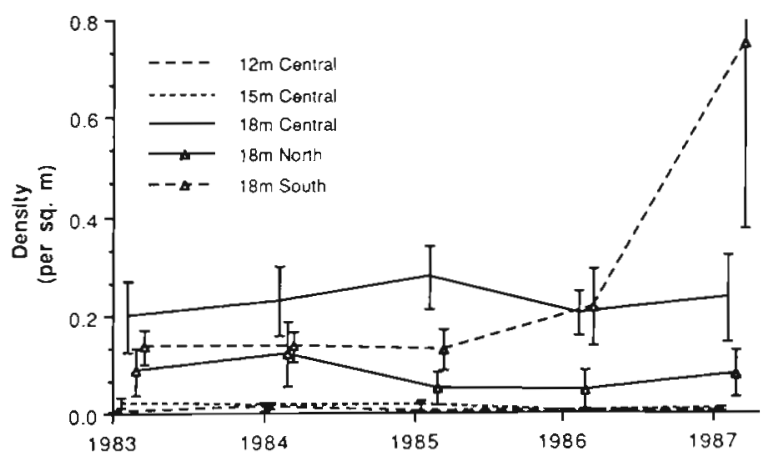

Fig. 7. Strongylocentrotus purpuratus and S. franciscanus. Densities of (A) purple urchins, and (B) red urchins, determined from annual censuses of the permanent transect lines, 1983 to 1987 . Error bars represent $95 \%$ confidence limits. There was a significant increase in the density of both species at $18 \mathrm{~m} \mathrm{~S}$ (see text)

(Tegner \& Dayton 1987); apparent grazing at $18 \mathrm{~m} \mathrm{~S}$ was noted in August but not perceived as exceptional because of the generally poor condition of Macrocystis pyrifera. Algal drift was similar at all 3 edge of forest sites in 1983-1984 (Fig. 1). In December 1984, after temperatures had returned to normal and the health of giant kelp plants had improved visibly, amphipod grazing holes were unmistakable in Macrocystis blades throughout the water column. By January 1985, most surface fronds at $18 \mathrm{~m} \mathrm{~S}$ were skeletons of stipes and pneumatocysts; blades less than $5 \mathrm{~m}$ off the bottom were healthy, blades from 5 to $10 \mathrm{~m}$ had many holes, and there were virtually no blades above $10 \mathrm{~m}$. In February 1985, an urchin front was discovered about $150 \mathrm{~m}$ southeast of $18 \mathrm{~m} \mathrm{~S}$. A $5 \mathrm{~m}$ chain was installed to anchor kelp along a portion of the front to determine whether the urchins' behavior was induced by food limitation; plants were tagged and urchins mapped in another $20 \mathrm{~m}$ of the front to follow the progress of the front. The anchored (and regularly replenished) kelp stopped the progress of the front near the chain; by early May the remainder of the front had grazed through 5 to $8 \mathrm{~m}$ of kelp forest. During this period the condition of the Macrocystis population continued to deteriorate and amphipod-produced drift may have slowed the progress of the front. By June, the remaining stipes of Macrocystis were only 3 to $4 \mathrm{~m}$ tall, and many giant kelp holdfasts had no stipes at all; moreover all of the laminarian understory also showed extensive damage from amphipod grazing. As amphipod grazing eliminated the differential in algal biomass between the 2 sides of the urchin front, the front dissipated. By mid 1985 the abundance of algal drift at $18 \mathrm{~m} \mathrm{~S}$ had decreased, but opportunistic red algae and Desmarestia ligulata and apparently some drift from less affected surrounding areas maintained supplies (Fig. 3). Surrounding stands of kelp were lost to amphipod grazing, and from December 1985 to July 1986, 6 of the 7 drift samples were less than $1 \mathrm{~g} \mathrm{~m}^{-2}$. Thus, a protracted period of low drift availability (Fig. 1), strong recruitment of both red and purple sea urchins in 1986 (Fig. 4), and apparently migration from south of line D (Fig. 8) led to significant increases in


Fig. 8. Strongylocentrotus purpuratus and S. franciscanus. Densities of (A) purple urchins, and (B) red urchins, determined from annual censuses of the permanent transect lines at $18 \mathrm{~m} \mathrm{~S}$ site, 1983 to 1987 , presented by line 
density of both urchin species in 1987 (Fig. 7) and intense urchin grazing along the permanent transect lines.

\section{A. Strongylocentrotus purpuratus}

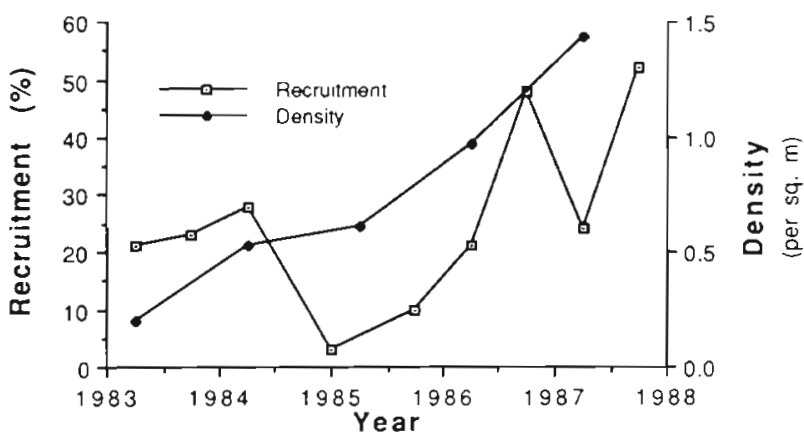

B. Strongylocentrotus franciscanus

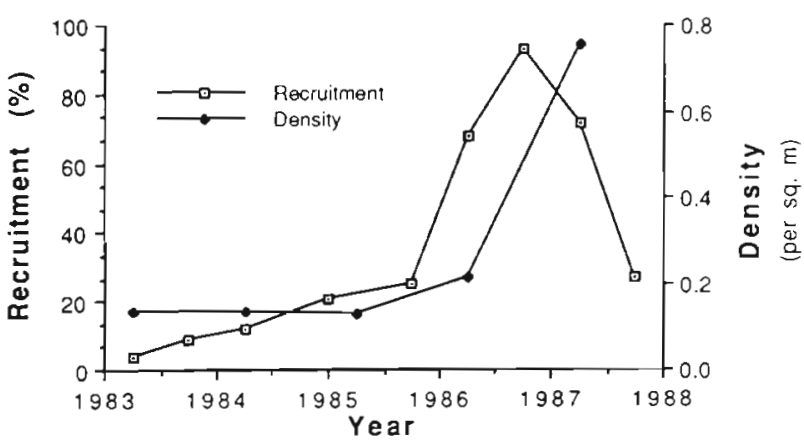

Fig. 9. Strongylocentrotus purpuratus and S. franciscanus Recruitment rates and densities of (A) purple urchins, and (B) red urchins, at the $18 \mathrm{~m} \mathrm{~S}$ site, 1983 to 1987 . Recruitment rates were determined from $\mathrm{m}^{2}$ samples of urchin aggregations and densities were determined from the permanent transect lines



Fig. 10. Strongylocentrotus purpuratus and S. franciscanus Comparison of purple and red urchin densities in 1975 and 1983-87 at 12 and $18 \mathrm{~m} \mathrm{C}$ sites determined from the transect Lines. Error bars represent $95 \%$ confidence limits

\section{Temperature patterns}

We collected in situ recording thermograph data throughout the course of this study; these are considered here to evaluate the hypothesis of Leighton et al. (1966) regarding temperature effects on sea urchin grazing by comparing the 3 similar depth edge sites. There was pronounced temporal (Fig. 11) and spatial variability in bottom temperatures, especially across the depth gradient of the forest (unpubl. data). The El Nin̄o years, 1983-1984, were dramatically warmer. To test for spatial variability in the longshore direction, monthly averages of 8 values per day were compared for the 3 similar depth, edge of forest stations for the period fall 1983 through spring 1987 using Friedman's 2-way ANOVA. Rankings were considered ties unless the temperature differential was $>0.3{ }^{\circ} \mathrm{C}$. The results showed significant $(0.05>p>0.01)$ differences between sites, and an a posteriori test (Nemenyi 1963) indicated that $18 \mathrm{~m} \mathrm{~N}$ was significantly $(\mathrm{p}<0.05)$ warmer than $18 \mathrm{~m} \mathrm{C}$ and $18 \mathrm{~m} \mathrm{~S}$; the latter 2 sites were not different.

\section{DISCUSSION}

\section{Changes in food supply}

The storms and warm water associated with the massive El Niño of 1982-84 caused extensive reductions in standing stock and much mortality of Macracystis pyrifera (Dayton \& Tegner 1984, Tegner \& Dayton 1987), the major component of the algal drift on which sea urchins feed (Table 1) and the preferred food of both Strongylocentrotus franciscanus and $S$. purpuratus (Leighton 1966). Storm and temperature effects on kelp standing stocks and growth rates related to the El Niño have been reviewed extensively (Tegner \& Dayton 1987, Dayton \& Tegner 1990), but are summarized here for their impact on sea urchin food availability. Typically half or more of the biomass of a healthy giant kelp population is found in the upper $1 \mathrm{~m}$ of the water column (North et al. 1982). The storms of the winter of 1982-83 led to virtually complete canopy loss at Point Loma and considerable (13 to 66\%) Macrocystis mortality which varied with depth and location in the forest. Upwelling during spring 1983 allowed plants which survived the storms to form a weak canopy by late spring; there was also much recruitment. However, the extraordinarily warm summer temperatures and associated nutrient reduction led to canopy deterioration and by October, the tops of most plants were 6 to $8 \mathrm{~m}$ below the surface. The growth of juvenile giant kelp plants, usually limited by light, became nutrient-limited as bottom irradiance levels 
Fig. 11. In situ bottom temperatures from the 3 outer edge of forest sites, $18 \mathrm{~m} \mathrm{~S}, 18 \mathrm{~m} \mathrm{C}$, and $18 \mathrm{~m} \mathrm{~N}, 1983$ to 1987. $18 \mathrm{~m} \mathrm{~N}$ is significantly warmer than the other 2 sites; the former 2 sites were not significantly different (see text)



were substantially higher during the El Nino (Dean \& Jacobsen 1986), and physiological stress caused by the warm temperature and low nutrient concentrations reduced photosynthetic capacity in juvenile and adult plants (Gerard 1984). Thus there was poor growth and extensive mortality of both Macrocystis recruits and adults which survived the storms. There was again some canopy formation during winter 1983-84, but the surface temperatures increased faster and summer surface temperatures were higher in 1984 than the year before (Tegner \& Dayton 1987). Thus the canopy also disappeared faster. Temperatures finally returned to the mean in November 1984 and the canopy began to recover quickly. There was no thermal stress in 1985 but the giant kelp canopy at Point Loma declined by almost $60 \%$ from January to July due to an infestation of grazing amphipods, apparently a secondary effect of the El Niño (Tegner \& Dayton 1987).

Thus there were several large-scale disturbances of the major source of algal drift during this $3 \mathrm{yr}$ period and, in comparison with the relatively normal year of 1986, these disturbances are reflected in the drift collections (Fig. 1). Most of the drift produced by the massive storms was apparently washed out of the forest as there was much kelp deposited on local beaches and in situ drift levels were very low when collections began in April 1983. Despite the small quantities of drift observed during the rest of this $3 \mathrm{yr}$ period, we did not observe a sea urchin behavioral switch from occupation of crevices and rock piles (where they feed primarily on drift algae) to open microhabitats and feeding on attached plants (Lees 1970, Dean et al. 1984, Ebeling et al. 1985, Harrold \& Reed 1985) at any of our 5 study sites. Apparently drift availability never fell below the threshold necessary to trigger this switch from passive detritivore to active grazer. During
1983-84, much of the drift consisted of decaying Macrocystis, suggesting that El Niño-induced deterioration was making up for much of the decrease in drift production due to lower standing stock. The kelp forest had recovered considerable biomass by the time of the amphipod infestation of 1985 and, with the exception of $18 \mathrm{~m} \mathrm{~S}$, this grazing episode increased drift availability to the benthos

The quantity of drift observed at Point Loma during 1983 to 1986 was about an order of magnitude less than what Gerard (1976) observed at Monterey and what Tutschulte \& Connell (1988) reported from Santa Catalina Island, but similar to what Harrold \& Reed (1985) found in a kelp forest on San Nicolas Island during non El Niño periods (see Fig. 7, Tegner \& Dayton 1987). These differences are likely to reflect the degree of exposure to wind and waves as well as productivity; both the Monterey and Santa Catalina Island sites are relatively protected making drift more likely to accumulate. Of the California drift studies, only Tutschulte \& Connell (1988) did not observe a seasonal cycle, but they did not sample during the winter.

Although no destructive levels of grazing by sea urchins were observed during the 1982-84 El Niño, the quantity and quality of the food appears to have affected them. Gonad indices of urchins reflect both the quantity and quality of food available (Lees 1970, Vadas 1977, Larson et al. 1980, Dean et al. 1984, Harrold \& Reed 1985). While we did not monitor gonad indices during this period, the roe yield of urchins harvested by the commercial fishery was lower than normal, often to the point of making processing uneconomical, and many processors closed (Kato \& Schroeter 1985). The Point Loma fishery remained open during the warm El Niño summers, but the yield dropped to between 40 and $50 \%$ of that recovered 
during previous summers (D. Rudie, Catalina Offshore Products, pers. comm.). It is likely that reduced gonad indices indicate less reproduction during this period.

\section{Changes in sea urchin grazing pressure}

There are examples in the literature where destructive sea urchin grazing episodes can be ascribed to a single, massive cohort of larvae (Camp et al. 1973) and some recruitment events of this kind can be tied to environmental anomalies (Foreman 1977, Hart \& Scheibling 1988). Hart \& Scheibling (1988) suggest that a large, positive temperature anomaly in June 1960 enhanced growth of Strongylocentrotus droebachiensis larvae leading to intense recruitment that year and the appearance of large adult populations 4 to $6 \mathrm{yr}$ later. This recruitment event may have led to the well-known destructive grazing problems in Nova Scotia. As El Niños in Southern California are associated with major environmental anomalies, which include temperature, current flow, and productivity (Chelton et al. 1982, McGowan 1985), and the El Nino of 1957-59 preceded an 'apparent population explosion' of sea urchins in previously healthy kelp forests (North \& Pearse 1970), the relationship between sea urchin recruitment and El Niños warrants consideration.

Kelp forests affect the spatial scales of recruitment by altering flow patterns, by providing clues for settlement, or as a result of predation by species associated with the forest (Pearse et al. 1970, Tegner \& Dayton 1981, Jackson \& Winant 1983, Gaines \& Roughgarden 1987). In the mid 1970 s, red urchin recruitment was highest near the outside edge of the Macrocystis pyrifera canopy, or in the center of the forest after localized disturbance of the canopy by storms (Tegner \& Dayton 1981). Three virtually complete losses of the giant kelp canopy thus created the potential for strong urchin recruitment throughout the bed during 1983-84, and the amphipod infestation greatly reduced the edge effect in 1985 (Tegner \& Dayton 1987). Instead urchin recruitment was much lower during 1983-85 than observed previously (Fig. 5). Purple urchins recruited strongly at $18 \mathrm{~m} \mathrm{~S}$ during 1983 and 1984, and red urchins recruited at $18 \mathrm{~m}$ $C$ in late 1983, but generally rates were very low from 1983 to 1985 (Fig. 4). Despite the absence of a surface canopy, the spatial pattern of urchin recruitment was the same as when the canopy was present. The 2 shallow water sites, $15 \mathrm{~m} \mathrm{C}$ and especially $12 \mathrm{~m} \mathrm{C}$, had the lowest urchin recruitment rates throughout the study, and there was no recruitment of Strongylocentrotus franciscanus observed at $12 \mathrm{~m} \mathrm{C}$ in 1985. Recruitment rates of both species increased in 1986-87 at sites near the edge of the forest (Fig. 4), and the rates at $18 \mathrm{~m}$ C were again comparable to the mid 1970 s (Fig. 5).
There are at least 3 potential explanations for the low rates of sea urchin recruitment observed at Point Loma during 1982-84 and it is likely that all were important. First, the storms caused massive damage to Macrocystis populations from Monterey in Central California to Isla Asuncion, Baja California, while the effects of the warm El Niño summers were most apparent from Santa Catalina Island to the southern end of the range of giant kelp (Tegner \& Dayton 1987). The widespread reductions in standing stocks of Macrocystis, the dependence of sea urchin gonad size on food availability (Lees 1970, Vadas 1977, Larson et al. 1980, Dean et al. 1984, Harrold \& Reed 1985), and the depressed state of the commercial red urchin fishery during this period (Kato \& Schroeter 1985) indicate that larval production must have been lower than normal over large portions of the ranges of both species. Second, the environment into which these relatively long-lived larvae (about 38 and $50 \mathrm{~d}$ in the laboratory for purple and red urchins, respectively; Cameron \& Schroeter 1980) were spawned was highy anomalous. The extremely low nutrient concentrations, surface productivity, and zooplankton biomass during 1983-84 (McGowan 1985) suggest that many planktotrophic larvae may have starved to death. Third, altered current patterns may have affected the transport of those larvae that did survive. El Niños in California are characterized by a weakened California Current and anomalously high levels of poleward flow (Chelton et al. 1982). Satellite imagery indicated that the California Current was displaced far offshore and that upwelling was much weaker than usual during the recent event. A greatly exaggerated Southern California eddy encompassed the northern Channel Islands of Southern California, even extending north of Point Conception (Fiedler 1984, Cowen 1985). While red and purple sea urchin recruitment was low at Point Loma during the El Nino, it was enhanced on the northern Channel Islands. Tegner \& Barry (unpubl.) found that red urchin recruitment was $50 \%$ higher and that purple urchin recruitment was $250 \%$ higher in 1984 than the averages for 1976 to 1982 at Johnsons Lee on Santa Rosa Island.

With algal drift availability at Point Loma apparently never low enough to trigger large-scale urchin foraging, and no increase in urchin recruitment to affect grazing pressure, it is not surprising that there were no significant increases in red or purple sea urchin density during the El Nino of 1982-84 (Fig. 7). The changes in urchin density and destructive grazing that were observed at $18 \mathrm{~m} \mathrm{~S}$ during 1986-87 followed a protracted period of low drift availability and increased urchin recruitment after the El Niño.

Leighton et al. (1966) hypothesized that the more rapid rise of sea urchin grazing rates relative to kelp growth rates in warm water would lead to an increase 
in grazing demand. The thermograph data allowed us to determine whether the destructive grazing by sea urchins at $18 \mathrm{~m} \mathrm{~S}$ can be attributed to warmer temperatures at this end of the forest. The results for the 3 similar depth, edge of forest sites, however, showed that $18 \mathrm{~m} \mathrm{~S}$ and $18 \mathrm{~m} \mathrm{C}$ were significantly cooler than $18 \mathrm{~m}$ $\mathrm{N}$. Purple urchin densities were higher at $18 \mathrm{~m} \mathrm{~N}$, the warmest edge of the forest site, than at $18 \mathrm{~m} \mathrm{~S}$ during 1983-84 and red urchins were present in comparable abundance (Fig. 6), yet there was no unusual urchin grazing observed at $18 \mathrm{~m} \mathrm{~N}$. Thus it does not appear that the destructive sea urchin grazing observed at $18 \mathrm{~m} \mathrm{~S}$ can be ascribed to warmer temperatures. The lack of any destructive grazing during the much warmer El Niño years (Fig. 11), or at any time during this study at the significantly warmer 12 and $15 \mathrm{~m}$ C sites (unpubl. data) suggests that temperature effects on grazing rates are less important than algal drift availability.

\section{Contrasts between El Niños of 1957-59 and 1982-84}

Scientists in 1957-59 were faced with a major environmental anomaly at a time when systematic investigation of kelp forest communities was just beginning. Furthermore, the relationship between El Niños, events defined off the coast of Peru, and changes in the California Current region was unknown (e.g. Sette \& Isaacs 1960). Thus the questions asked, methods, and data collected were very different during these 2 events and strict comparisons cannot be made. Here we discuss the data that are available from the 1950 s and 1960s, the changes that have taken place since that period, and eventually speculate about what happened during the 1957-59 El Niño on the basis of our data from the recent event.

The El Niños of 1957-59 and 1982-84 were both catastrophic-scale disturbances, but the 2 events differed physically and had different implications for kelp forest community structure. There were 4 wave episodes exceeding $3 \mathrm{~m}$ in 1957-59 but 10 such episodes during the latter El Niño, an unprecedented record (Seymour et al. 1984). The earlier warm water El Niño persisted longer but the 1982-84 event included a substantial period of unparalleled high sea-surface temperature (North 1985). Because the large temperature anomalies exacerbated the effects of the storms, we believe that the recent El Niño was a larger disturbance than the 1957-59 event. Nevertheless, the Point Loma kelp forest showed significant recovery the year following the 1982-84 event, something that took $5 \mathrm{yr}$ in the 1960s (Tegner \& Dayton 1987).

Several important factors were different between these 2 events. First, the extraordinarily stormy winter of 1982-83 followed by spring upwelling facilitated massive recruitment of giant kelp during 1983. While most recruits died during the subsequent period of warm water, this recruitment event may have provided a small but important source of drift algae for the urchins in the interim. W. J. North's aerial photographs of the Point Loma kelp forest canopy (see Fig. 11, Tegner \& Dayton 1987), however, show more canopy in 1958 and 1959 than 1983 and 1984, suggesting that without the storm-induced destruction of Macrocystis, giant kelp stocks and thus drift availability were higher during the earlier El Niño. Second, sewage disposal practices of the late 1940 s and 1950s apparently contributed to substantial decline of the Point Loma kelp forest before the El Niño of 1957-59. Deterioration began in the south end of the forest nearest the discharge, a shallow site inside San Diego Bay, and progressed northward through the forest from there (North 1964, Wilson et al. 1977). The outfall was moved to its present deep water, offshore location in 1963. Third, spiny lobsters Panulirus interruptus and sheephead Semicossyphus pulcher, the important predators of strongylocentrotids in Southern California, had been heavily fished for many years (Tegner 1980, Tegner \& Dayton 1981, Cowen 1983, Tegner \& Levin 1983). Thus even small reductions in drift availability in 1957-59 were likely to have been enough to push an already out of balance situation towards destructive grazing (Dean et al. 1984, Ebeling et al. 1985, Harrold \& Reed 1985). The late 1960 s recovery of the Point Loma kelp forest was facilitated by improvements in waste water disposal, kelp restoration, and sea urchin control efforts which began in 1963 (North 1965, 1983, Leighton et al. 1966). Thus, while the disturbances associated with the 1982-84 El Niño apparently were larger, the destabilized kelp forests of the late 1950s were more severely affected (Tegner \& Dayton 1987).

The red urchin fishery, which originated in the early 1970 s (Kato \& Schroeter 1985), began serious growth in San Diego during the mid 1970s (Fig. 12), and is now fully exploited in Southern California (Tegner 1989). The fishery began in shallow water and decreases were seen in the proportions of large individuals at the 12 and $15 \mathrm{~m}$ Central sites from 1976 on (Tegner \& Dayton 1981). The number of urchin boats working the San Diego coastline grew steadily from about half a dozen in 1977 to 25 in 1982. A combination of the El Niño, overharvesting, and price drops left only 3 urchin boats fishing locally in 1983. Environmental conditions, stocks, and prices recovered to the degree that 7 or 8 boats were harvesting in 1986-87. The average size of sea urchins landed has also declined; there is now a $75 \mathrm{~mm}$ minimum size limit (D. Rudie, Catalina Offshore Products, pers. comm.). This historical record correlates with the data in Fig. 6; most of the decline in the density of red urchins larger than $100 \mathrm{~mm}$ took place 


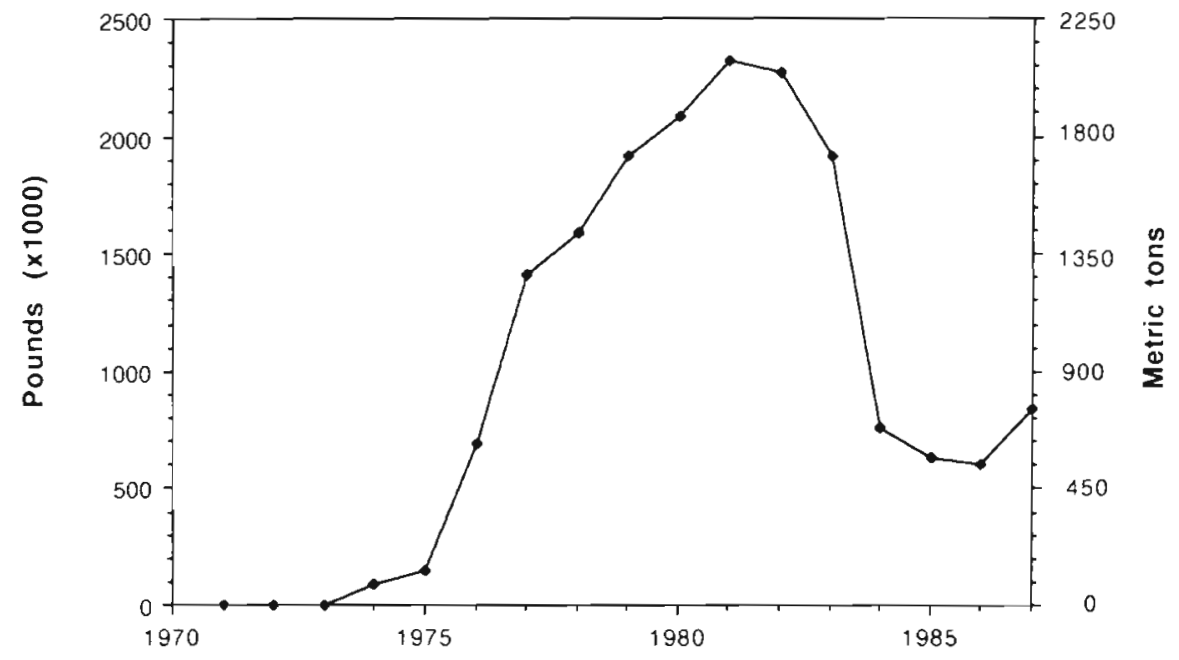

Fig. 12. Stronglyocentrotus franciscanus. Red sea urchins landed by the commercial fishery in San Diego (Califormia Department of Fish and Game, unpubl. data). These data include individuals fished at Point Loma and nearby areas; the tempor. al pattern but not the total landings are an accurate reflection of sea urchin fishing at Point Loma (D. Rudie, Catalina Offshore Products, pers. comm. )

between 1977 and 1983, the period of major growth in the fishery. The impact of the fishery is most apparent within the forest; red urchins are now rare at $12 \mathrm{~m} \mathrm{C}$ (Fig. 10). We moved the area monitored for urchin density at $15 \mathrm{~m} \mathrm{C}$ in 1983, but observations of the old area and the drop in recruitment rate in the boulder pile samples at this site (Fig. 5) suggest that the red urchin population is declining at $15 \mathrm{~m} \mathrm{C}$ as well. Thus with the elimination of unfished stocks throughout the forest, it appears that only the edge of forest sites are recruiting at rates sufficient to support the fishery.

The decline in red urchin recruitment rates at forest interior sites could be related to a decrease in total larval availability and thus fewer larvae penetrating into these sites, or to loss of the adult spine canopies important to the survival of young of the year individuals (Tegner \& Dayton 1977, Tegner \& Levin 1983), or almost certainly both. Comparison of the recruitment patterns at the 12 and $18 \mathrm{~m} \mathrm{C}$ sites (Fig. 6) suggests the possibility of an adult threshold density necessary for successful juvenile recruitment. The efficiency of the commercial fishery decreases with depth. Some large adults continue to be present in the population at most sites because the unit price of an urchin is too low to justify the time required to harvest urchins at low density or in cryptic habitats (e.g. under rocks). The average price per pound of red urchins harvested in San Diego was US $\$ 0.65$ for the first 5 mo of 1989 (D. Rudie, Catalina Offshore Products, pers. comm.). An experiment is underway to determine whether the decreased recruitment at $12 \mathrm{~m} \mathrm{C}$ is the result of reduced adult red urchin density. It should be noted that purple urchin recruitment rates were also low at the 2 forest interior sites in the mid 1980s (Fig. 5). In the absence of a commercial fishery on this species it is unlikely that its larval production was down, but juven- iles of this species were once also common under red urchin spine canopies (Tegner \& Dayton 1977).

Whatever the cause of reduced recruitment in the interior of the bed, these data suggest that red urchin populations are now ecologically significant in a much smaller portion of the forest. While both species of Strongylocentrotus at Point Loma are important kelp grazers, the red urchin, by virtue of its much larger size, higher feeding capacity per individual (Leighton 1971), and lower susceptibility to predation by spiny lobsters and sheephead as adults (Tegner \& Levin 1983) relative to the purple urchin, may be the more destructive to kelp populations. We observed 2 major episodes of grazing by urchins at $12 \mathrm{~m} \mathrm{C}$ in the $1970 \mathrm{~s}$; both virtually eliminated Macrocystis from the area (Dayton et al. 1984). There were no destructive grazing episodes from 1983 through 1987 at this location despite similar densities of purple urchins to the mid 1970s.

\section{CONCLUSIONS}

El Niños, including the strong events which disturb temperate ecosystems in the northern hemisphere, are a regular feature of the eastern Pacific Ocean (e.g. Quinn et al. 1978, Cannon et al. 1985). The 1982-84 event offered an opportuntity to reexamine how strong El Niños affect the relationship between kelps and sea urchins in Southern California with regard to the changes that have taken place in the Point Loma kelp forest since 1957-59.

There were no episodes of destructive grazing by sea urchins observed during the El Niño of 1982-84, and only $18 \mathrm{~m} \mathrm{~S}$ was overgrazed during the $5 \mathrm{yr}$ course of this study. This occurred after an infestation of grazing amphipods, apparently a secondary result of the El 
Niño (Tegner \& Dayton 1987, Dayton \& Tegner 1990), eliminated most of the algal standing stock (and thus the local source of drift) in this region. After several months of very low drift availability in late 1985 and 1986, sea urchins switched from being passive detritivores to active grazers and destroyed the few recruits of Macrocystis pyrifera left on the transect lines at the South site. There was a similar peracarid crustacean outbreak at Point Loma during the winter of 1965. In this case the surface canopy of Macrocystis was eliminated between stations $2.4 \mathrm{~km}$ apart but plants appeared normal below $3 \mathrm{~m}$ (Jones 1965); giant kelp stocks and drift supplies were probably not as severely affected as in 1985.

The El Niños of 1957-59 and 1982-84 differed physically in aspects other than the number of large wave episodes and the size of the temperature anomaly (e.g. McGowan 1985), but probably had very similar effects on Macrocystis pyrifera populations and sea urchin recruitment. North (1964) reported that virtually all the kelp was eliminated at Point Loma during the warm water period of 1957-59 and even the Channel Island forests were in poor shape. Abalones (Haliotis spp.) are also macroalgal detritivores and Cox (1962) reported that abalone growth practically ceased, body tissues appeared to shrink, and that there was a shortage of new individuals entering the fishery during the 1957-59 El Niño. Abalone gonads did not increase in size during their regular spawning season and many individuals were probably unable to spawn. Reduced gonad development of green abalones $H$. fulgens on the Palos Verdes Peninsula near Los Angeles suggested that these missed their spring spawning in 1983 because of El Niño effects on their food supply (Tegner \& Dayton 1987). It is clear that both events were characterized by greatly reduced kelp standing stocks, impoverished pelagic communities, and altered current patterns (Chelton et al. 1982, North 1983, McGowan 1985), the conditions apparently responsible for the poor urchin recruitment observed at Point Loma during the 1982-84 El Niño.

In the absence of evidence for increased recruitment or temperature effects on grazing demand, it appears that the destructive urchin grazing problems of the late 1950 s and early 1960 s resulted from reductions in standing stocks and productivity of Macrocystis pyrifera below levels necessary to satisfy existing grazing demand. The density of sea urchins had probably been increasing slowly as the abundances of spiny lobsters and sheephead were reduced by fishing (Tegner 1980, Tegner \& Levin 1983). That, combined with the chronic effects of sewage disposal and especially the coup de grace delivered by the El Nino of 1957-59, reduced the ratio of kelp biomass to urchin biomass sufficiently to trigger active grazing. Once established, urchin bar- rens may persist for several years (North 1964, 1983, reviewed by Dayton 1985). Sea urchin control, kelp restoration, and improvements in sewage disposal practices were all involved in the recovery of the Point Loma kelp forest by the late 1960s. While the local kelp harvesting company still reports localized patches of destructive grazing, especially by purple urchins ( $M$. Otjens, Kelco, pers comm.), our data suggest that the red urchin fishery has enhanced the ability of the Point Loma kelp forest to recover from catastrophic-scale disturbances.

Acknowledgements. We thank R. Butler, G. Chen, T. Klinger, C. Lennert, P. Parnell, K. Plummer, and L. Walcheff for many hours underwater. P. Edwards, P. Parnell, D. Rice, and L. Walcheff assisted with data analysis and graphics, E. Venrick advised on statistics, and D. Parker and D. Rudie provided fishery data. J. Barry, N. Holland, and anonymous reviewers provided valuable comments on the manuscript. This work is a result of research sponsored by NSF, the California Department of Fish and Game, the UCSD Academic Senate, and NOAA, National Sea Grant College Program, Department of Commerce, under grant number NA80AA-D-00120, project number R/NP-1-12F, through the California Sea Grant Program. The US Government is authorized to reproduce and distribute for governmental purposes

\section{LITERATURE CITED}

Breen, P. A., Carolsfeld, W., Yamanaka, K. L. (1985). Social behaviour of juvenile red sea urchins, Strongylocentrotus franciscanus (Agassiz). J. exp. mar. Biol. Ecol. 92: 45-61

Cameron, R. A., Schroeter, S. C. (1980). Sea urchin recruitment: effect of substrate selection on juvenile distribution. Mar. Ecol. Prog. Ser. 2: 243-247

Camp, D. K., Cobb, S. P., Van Breedveld, J. F. (1973). Overgrazing of seagrasses by a regular urchin, Lytechnius variegatus. Bioscience 23: 37-38

Cannon, G. A., Reed, R. K., Pullen, P. E. (1985). Comparison of El Niño events off the Pacific Northwest. In: Wooster, W S., Fluharty, D. L. (eds.) El Niño north, Niño effects in the eastern subarctic Pacific. Washington Sea Grant Program, University of Washington, Seattle, p. 75-84

Chelton, D. P., Bernal, P. A., McGowan, J. A. (1982), Largescale interannual physical and biological interactions in the California Current. J. mar. Res. 40: 1095-1125

Cowen, R. K. (1983). The effect of sheephead (Semicossyphus pulcher) predation on red sea urchin populations: an experimental analysis. Oecologia 58: 249-255

Cowen, R. K. (1985). Large scale patterns of recruitment by the labrid, Semicossyphus pulcher: causes and implications. J. mar. Res. 43: 719-742

Cox, K. W. (1962). California abalones, family Haliotidae. Calif. Dept. Fish Game, Fish. Bull. 118: 1-133

Dayton, P. K. (1985). Ecology of kelp communities. Ann. Rev. Ecol. Syst. 16: 215-245

Dayton, P. K., Currie, V., Gerrodette, T., Keller, B. D., Rosenthal, R., Ven Tresca, D. (1984). Patch dynamics and stability of some California kelp communities. Ecol. Monogr. 54: 253-289

Dayton, P. K., Tegner, M. J. (1984). Catastrophic storms, El Niño, and patch stability in a Southern California kelp community. Science 224: 283-285 
Dayton, P. K., Tegner, M. J. (1990). Bottoms below troubled waters: benthic impacts of the 1982-1984 El Nino in the temperate zone. In: Glynn, P. W. (ed.) Global ecological consequences of the 1982-83 El Niño-Southern Oscillation. Elsevier Oceanography Series No. 52, Amsterdam, p. $433-472$

Dean, T A., Schroeter, S. C., Dixon, J. D. (1984). Effects of grazing by two species of sea urchins (Strongylocentrotus franciscanus and Lytechinus anamesus) on recruitment and survival of two species of kelp (Macrocystis pyrifera and Pterygophora californica). Mar. Biol. 78: 301-313

Dean, T. A., Jacobsen, F. R. (1986). Nutrient-limited growth of juvenile kelp, Macrocystis pyrifera, during the 1982-1984 'El Nin̄o' in Southern California. Mar. Biol. 90: 597-601

Druehl, L. D., Breen, P. A. (1986). Some ecological effects of harvesting Macrocystis integrifolia. Botanica mar. 29: 97-103

Ebeling, A. W., Laur, D. R., Rowley, R. J. (1985). Severe storm. disturbances and reversal of community structure in a southern California kelp forest. Mar. Biol. 84: 287-294

Ebert, T. A. (1977). An experimental analysis of sea urchin dynamics and community interactions on a rock jetty. J. exp. mar. Biol. Ecol. 27: 1-22

Fiedler, P. C. (1984). Satellite observations of the 1982-83 El Niño along the US Pacific coast. Science 224: 1251-1254

Foreman, R. E. (1977). Benthic community modification and recovery following intensive grazing by Strongylocentrotus droebachiensis. Helgoländer wiss. Meeresunters. 30: $468-484$

Gaines, S. D., Roughgarden, J. (1987). Fish in offshore kelp forests affect recruitment to intertidal barnacle populations. Science 235: 479-481

Gerard V A. (1976). Some aspects of material dynamics and energy flow in a kelp forest in Monterey Bay. Ph.D. dissertation, University of California, Santa Cruz

Gerard, V A. (1984). Physiological effects of El Niño on giant kelp in Southern California. Mar. Biol. Lett. 5: 317-322

Harger, B. W. (1983). An historical overview of kelp in Southern California. In: The effects of waste disposal on kelp communities. Bascom, W, (ed.) Southern California Coastal Water Research Project, Long Beach, p. 70-83

Harrold, C., Reed, D. C. (1985). Food availability, sea urchin grazing, and kelp forest community structure. Ecology 86 : 1160-1169

Hart, M. W., Scheibling, R. E. (1988). Heat waves, baby booms, and the destruction of kelp beds by sea urchins. Mar. Biol. 99: 167-176

Jackson, G. A., Winant, C. D. (1983). Effect of a kelp forest on coastal currents. Cont. Shelf Res. 2: 75-80

Jones, L. G. (1965). Canopy grazing at southern Point Loma. In: North, W J. (ed.) Kelp habitat improvement project annual report, 1 Feb. 1964 - 31 Mar. 1965. W M. Keck Laboratory of Environmental Health and Engineering, California Institute of Technology, Pasadena, p. 62-63

Kato, S., Schroeter, S. C. (1985). Biology of the red sea urchin, Strongylocentrotus franciscanus, and its fishery in California. Mar. Fish. Rev. 47:1-20

Larson, B. R., Vadas, R. L., Keser, M. (1980). Feeding and nutritional ecology of the sea urchin Strongylocentrotus droebachiensis in Maine, USA. Mar. Biol. 59: 49-62

Lees, D. C. (1970). The relationship between movement and available food in the sea urchins Strongylocentrotus franciscanus and Strongylocentrotus purpuratus. M.S. thesis, San Diego State College, San Diego, California, 117pp.

Leighton, D. L. (1966). Studies of food preference in algivorous invertebrates of Southern California kelp beds. Pacif. Sci. 20: $104-113$
Leighton, D. L. (1971). Grazing activities of benthic invertebrates in kelp beds. Nova Hedwigia 23: 421-453

Leighton, D. L., Jones, L. G., North, W. J. (1966). Ecological relationships between giant kelp and sea urchins in South. ern California. In: Young, E., G., McLachlan, J. L. (eds.) Proc. fifth Annual Seaweed Symposium. Pergamon Press, Oxford, p. 141-153

Mearns, A. J., Young, D. R. (1983). Appendix A. Characteristics and effects of municipal wastewater discharges to the Southern California Bight, a case study. In: Meyers, E. P. Harding, E. T. (eds.) Ocean disposal of municipal wastewater: impacts on the the coastal environment. Sea Grant College Program, Massachusetts Institute of Technology. Cambridge, Massachusetts, p. 762-819

McGowan, J. A. (1985). El Nirio 1983 in the Southern California Bight. In: Wooster, W. S., Fluharty, D. L. (eds.) El Niño north, Nin̄o effects in the eastern subarctic Pacific. Washington Sea Grant Program, University of Washington, Seattle, p. $166-184$

Nemenyi, P. (1963). Distribution-free multiple comparisons. Ph.D. dissertation, Princeton University, Princeton, New Jersey

North, W. J. (ed.) (1964). An investigation of the effects of discharged wastes on kelp. Publ. No. 26. The Resource Agency of California, State Water Quality Control Board

North, W. J. (ed.) (1965). Kelp habitat improvement project. Annual Report, 1 February 1964 - 31 March 1965. W. M. Keck Laboratory of Environmental Engineering, California Institute of Technology, Pasadena, California

North, W J (ed.) (1971). The biology of giant kelp beds (Macrocystis) in California. Beih. Nova Hedwigia 32: 1-600

North, W. J. (ed.) (1974). Kelp habitat improvement project Annual Report, 1 July 1973 - 30 June 1974. W. M. Keck Laboratory of Environmental Engineering, California Institute of Technology, Pasadena, California

North, W. J. (1983). The sea urchin problem. In: Bascom, W. (ed.) The effects of waste disposal on kelp communities. Southern California Coastal Water Research Project, Long Beach, p. 243-255

North, W. J. (1985). Health of kelp beds. In: Report on 1984 Data, Marine Environmental Analysis and Interpretation, San Onofre Nuclear Generating Station, Southern California Edison 85-RD-37: p. 6-1-6-43

North, W. J., Gerard, V A., Kuwabara, J. (1982). Farming Macrocystis at coastal and oceanic sites. In: Srivastava, L. M. (ed.) Synthetic and degradative processes in marine macrophytes. De Gruyter, New York, p. 247-262

North, W. J., Pearse, J. S. (1970). Sea urchin population explosion in Southern California coastal waters. Science 167: 209

Pearse, J. S., Clark, M. E., Leighton, D. L., Mitchell, C. T., North, W. J. (1970). Marine waste disposal and sea urchin ecology. In: Kelp habitat improvement project, W. J. North, principal investigator, Ann. Rep. 1969-70, California Institute of Technology, p. 1-93

Quinn, W. H., Zopf, D. O., Short, K. S., Kuo Yang, R. T W. (1978). Historical trends and statistics of the southern oscillation. El Niño, and Indonesian droughts. Fish. Bull. U.S. 76: 663-678

Sette, O. E., Isaacs, J. D. (1960). Symposium on the changing Pacific Ocean in 1957 and 1958. California Cooperative Oceanic Fisheries Investigations Repts. VII: 13-217

Seymour, R. J., Strange III, R. R., Cayan, D. R., Nathan, R. A. (1984). Influence of El Niños on California's wave climate. In: Edge, B. L. (ed.) Nineteenth Coastal Engineering Conference, Proceedings of the International Conference, Sept. 3-7, 1984, Houston, Texas. Am. Soc. Civil Engineers, New York, Vol. I, p. 577-592 
Sokal, R. R., Rohlf, F. J. (1969). Biometry. W. H. Freeman and Co., San Francisco

Tegner, M. J. (1980). Multispecies considerations of resource management in Southern California kelp beds. Can. Tech. Rep. Fish. Aquat. Sci. 945: 125-143

Tegner, M. J. (1989). The feasibility of enhancing red sea urchin (Strongylocentrotus franciscanus) stocks in California; an analysis of the options. Mar. Fish. Rev. 51(2): 1-22

Tegner, M. J., Dayton, P. K. (1977). Sea urchin recruitment patterns and implications of commercial fishing. Science 196: $324-326$

Tegner, M. J., Dayton, P. K. (1981). Population structure, recruitment, and mortality of two sea urchins (Strongylocentrotus franciscanus and $S$. purpuratus) in a kelp forest. Mar. Ecol. Prog. Ser. 5: 255-268

This article was presented by N. Holland, La Jolla, California, USA
Tegner, M. J., Dayton, P. K. (1987). El Niño effects on Southern California kelp forest communities. Adv. ecol. Res. 17: 243-279

Tegner, M. J., Levin, L. A. (1983). Spiny lobsters and sea urchins: analysis of a predator-prey interaction. J. exp. mar Biol. Ecol. 73: 125-150

Tutschulte, T C., Connell, J. H. (1988). Feeding behavior and algal food of three species of abalones (Haliotis) in Southern California. Mar Ecol. Prog. Ser. 49: 57-64

Vadas, R. L. (1977). Preferential feeding: an optimization strategy in sea urchins. Ecol. Monogr. 47: 337-371

Wilson, K. C., Haaker, P. L., Hanan, D. A. (1977). Kelp restoration in Southern California. In: Krauss, R. (ed.) The marine plant biomass of the Pacific Northwest coast. Oregon State University Press, Corvallis, p. 183-202

Manuscript first received: November 6, 1989 Revised version accepted: August 21, 1991 